\title{
Pola Kemitraan Usaha Tani Kelapa Sawit Kelompok Tani Telaga Biru dengan PT. Sawindo Kencana melalui Koperasi di Kabupaten Bangka Barat Provinsi Bangka Belitung
}

\author{
I MADE GANNAL DWI SAPUTRA, I G A A LIES ANGGRENI, \\ I PUTU DHARMA \\ Program Studi Agribisnis, Program Non Reguler, Fakultas Pertanian \\ Universitas Udayana \\ J1. PB Sudirman Denpasar 80232 Bali \\ Email: made.gannal@gmail.com \\ liesanggreni@gmail.com
}

\begin{abstract}
Farming Partnership of Palm Oil Farmers Group of Telaga Biru, with PT. Sawindo Kencana in West Bangka of Bangka Belitung.
\end{abstract}

This research is to determine the mechanism of partnership between PT. Sawindo Kencana with farmer groups of Telaga Biru through cooperatives, farmers' rights and obligations and the company as well as the role of the position of the institutions concerned, the effectiveness of cooperation, and obstacles encountered in the course of the partnership. Location of research was selected by using purposive sampling. The type of data includes quantitative and qualitative data derived from primary and secondary data. Methods of data collection are interviews and documentation. Data analysis was conducted by using qualitative and quantitative descriptive method. The research results showed that the mechanism of implementation of the partnership based on a written agreement between farmers' groups of Telaga Biru and PT. Sawindo Kencana already realized well. The rights of farmers are to obtain the seeds, fertilizers, crop tool, material of pesticides, and marketing of the crop. The rights of the company is to obtain the harvest from farmers. Obligations of farmers namely provide crop yields of quality palm oil. The company's obligation namely to provide the needs of farmers such as fertilizer, harvesting equipment, materials of pesticides, and crop yields rights. The effectiveness of cooperation, namely the certainty of the role of the farmer groups of Telaga Biru in the company in partnership was not running optimally, but the certainty of the role of the company is already well underway. Obstacles in the farmer group of Telaga Biru namely that the farmers 'background is different, lacking the discipline of saving money, and lack of participation in the care of smallholdings.

Keywords: partnership pattern, palm oil, mechanism 


\section{Pendahuluan}

\subsection{Latar Belakang}

Perkembangan usaha agribisnis di Indonesia telah membuka wacana baru dalam praktek-praktek agribisnis yang dilakukan terutama oleh petani atau pembudidaya. Salah satu bentuk usaha agribisnis yang cukup banyak dilakukan adalah dengan konsep kemitraan. Beberapa perusahaan mencoba untuk menawarkan konsep kemitraan ini kepada para petani untuk memproduksi suatu komoditas tertentu dan menjamin pemasaran hasil produksinya.

Konsep dan pola kemitraan yang ditawarkan antara satu perusahaan dengan perusahaan lain berbeda-beda. Beberapa hal yang mempengaruhi konsep dan pola kemitraan adalah jenis komoditas yang dibudidayakan, permintaan konsumen dari komoditas yang dibudidayakan, serta pangsa pasar dari komoditas yang dibudidayakan (Kurnianti, 2013).

PT. Sawindo Kencana merupakan perusahaan pertama yang menjalankan kemitraan pada tahun 1997 dengan 25 kelompok tani di Kecamatan Tempilang termasuk kelompok tani Telaga Biru. Kemitraan hadir sebagai pemecah masalah untuk mendongkrak perekonomian rakyat di kabupaten Bangka Barat. Pola kemitraan yang ada saat ini merupakan kelanjutan, peningkatan, perluasan, penataan, dan pemantapan dari kerja sama kemitraan sebelumnya. Secara garis besar, di Indonesia terdapat lima pola kemitraan, yaitu Pola PIR, Pola Subkontrak, Pola kemitraan perdagangan umum, Pola kemitraan keagenan, dan Pola KKPA. Sistem kemitraan KKPA di Desa Tanjung Niur terjadi karena adanya saran dari PT. Sawindo Kencana dengan pemerintah Kabupaten Bangka Barat untuk mendirikan pola kemitraan. Kemitraan ini merupakan upaya untuk mensejahterakan petani.

Mekanisme kemitraan yang dilakukan dengan tujuan untuk mengukur sejauh mana tujuan tersebut dapat tercapai. Ide awal yang mengadakan kemitraan adalah PT. Sawindo Kencana selaku perusahaan. Walaupun pada saat awal terjadinya proses kemitraan, perusahaan mengalami kendala yaitu sebelum diadakannya kerja sama, PT. Sawindo Kencana dalam melakukan kerja sama dengan kelompok petani Telaga biru kurang adanya sosialisasi dengan kelompok tani.

Banyak masyarakat khususnya petani menganggap bahwa kemitraan yang dilakukan oleh perusahaan dapat merugikan masyarakat dan hanya menguntungkan pada pihak perusahaan saja. PT. Sawindo Kencana pada awalnya melihat potensi yang dimiliki oleh masyarakat Desa Tempilang memiliki potensi cukup besar dalam budidaya kelapa sawit. Melihat hal itu PT. Sawindo Kencana mengajak masyarakat untuk bekerja sama dalam membudidayakan kelapa sawit dengan membuat perjanjian bersama dengan masyarakat, dan membentuk kelompok petani yang bersedia untuk melakukan kerja sama dengan perusahaan..

Keberhasilan pola kemitraan tergantung pada penerapannya. Sunarko (2009) mengatakan, kunci kemitraan adalah suatu proses yang memerlukan peningkatan intensitas hubungan inti dan plasma berdasarkan kepercayaan satu dengan yang lainnya yang nyata dan terukur. Kemitraan harus terdapat komitmen yang saling 
memuaskan kedua pihak dan menumbuhkan saling ketergantungan. Tolak ukur keberhasilan kemitraan dapat dilihat dari mekanisme, hak dan kewajiban, serta efektivitas kerjasama yang dilakukan kedua belah pihak. Menyingkapi permasalahan diatas, maka perlu dilakukan penelitian tentang bagaimana mekanisme pola kemitraan, hak dan kewajiban, efektivitas kerja sama, serta kendala yang dihadapi oleh inti dan plasma.

\subsection{Tujuan Penelitian}

Penelitian ini bertujuan untuk mengetahui mekanisme kemitraan dalam pengembangan budidaya kelapa sawit, hak dan kewajiban, efektivitas kerjasama serta kendala yang dihadapi kelompok tani Telaga Biru dan PT. Sawindo Kencana dalam melaksanakan pola kemitraan pengembangan budidaya kelapa sawit di Desa Tanjung Niur, Kecamatan Tempilang, Kabupaten Bangka Barat.

\section{Metode Penelitian}

\subsection{Lokasi dan Waktu Penelitian}

Penelitian dilaksanakan pada Kelompok Tani Telaga Biru dan PT. Sawindo Kencana di Desa Tanjung Niun Kecamatan Tempilang, Kabupaten Bangka Barat dan dilakukan pada bulan Desember 2015. Pemilihan lokasi ditentukan secara sengaja (purposive).

\subsection{Penentuan Informan Kunci}

Informan adalah orang yang memberi informasi atau orang yang menjadi sumber data dalam penelitian (Wikipedia, 2015). Informan kunci dalam penelitian ini dipilih secara sengaja (purposive) yaitu pengambilan hanya pada individu yang didasarkan pada pertimbangan dan karakteristik tertentu (Suharsaputra, 2012). Penelitian ini dipilih sebanyak tiga orang sebagai informan kunci yang terdiri atas ketua kelompok tani, ketua koperasi, dan teknisi perusahaan. Informan kunci tersebut dipilih dengan pertimbangan tingkat pemahaman dan memiliki pengaruh dalam pola kemitraan kelapa sawit antara Kelompok Tani Telaga Biru dengan PT. Sawindo Kencana.

\subsection{Metode Pengumpulan Data, Variabel Penelitian, dan Metode Analisis Data}

Pengumpulan data dilakukan dengan cara wawancara mendalam dan dokumentasi. Variabel dalam penelitian ini terdiri dari mekanisme pola kemitraan, hak dan kewajiban, efektivitas kerjasama, serta kendala-kendala yang dihadapi dalam pola kemitraan kelapa sawit antara Kelompok Tani Telaga Biru dengan PT. Sawindo Kencana. Metode analisis data yang digunakan dalam penelitian ini adalah deskriptif kualitatif dan kuantitatif. 


\section{Hasil dan Pembahasan}

\subsection{Karakteristik Informan Kunci}

Karakteristik informan kunci adalah gambaran mengenai identitas informan kunci yang digunakan dalam penelitian ini. Karakter infoman kunci dalam penelitian ini meliputi jenis kelamin, umur, dan tingkat pendidikan seperti pada Tabel 1 berikut.

Tabel 1.

Karakteristik Informan Kunci

\begin{tabular}{clccc}
\hline No & \multicolumn{1}{c}{ Informan } & Jenis Kelamin & Umur & Tingkat Pendidikan \\
\hline 1 & Teknisi Lapangan & Pria & 38 & Sarjana (S1) \\
2 & Ketua Kelompok Tani & Pria & 65 & SD \\
3 & Ketua Koperasi & Pria & 53 & SD \\
\hline
\end{tabular}

Sumber : Data Primer, 2015.

\subsection{Mekanisme Pola Kemitraan}

Pengertian mekanisme adalah interaksi bagian satu dengan yang lainnya dalam suatu sistem secara keseluruhan untuk menghasilkan fungsi atau kegiatan sesuai dengan tujuan (Bagus, 1996). Pola kemitraan yang diterapkan oleh PT. Sawindo dengan kelompok Tani Telaga Biru adalah pola kemitraan inti plasma.

Proses perjanjian dan kesepakatan yang dilakukan merupakan perjanjian yang menguntungkan bagi kedua belah pihak, seperti simbiosis mutualisme yang artinya saling menguntungkan. Dimana perusahaan berperan sebagai inti dan petani sebagai plasma. Peran perusahaan sebagai inti yaitu perusahaan merupakan wadah penerima hasil panen dari petani dan tempat pemasaran hasil panen yang di dapatkan dari petani, sedangkan petani sebagai plasma yaitu petani hanya menyiapkan lahan untuk dikelolah oleh perusahaan dan menerima hasil sebanyak 70\% dan $30 \%$ sisanya untuk membayar hutang di bank. Bank memberikan daftar sisa hutang dan realisasi cicilan kepada petani melalui perusahaan untuk diteruskan kepada koperasi secara berkala, antara 3 bulan dan 6 bulan sekali.

Bentuk kerjasama yang dijalankan yaitu dengan pola KKPA dalam proyek budidaya kelapa sawit. KKPA atau Kredit Koperasi Primer untuk Anggota adalah fasilitas kredit yang diberikan kepada petani peserta melalui KUD dan dipergunakan untuk membangun kebun anak angkat (Yarsi, 2006). Pengadaan tanah kebun plasma KKPA project berasal dari penyerahan tanah oleh pemilik/penguasa tanah yang diserahkan kepada Negara melalui pemerintah daerah yang selanjutnya diperuntukan bagi kelompok tani peserta plasma untuk dijadikan areal kebun plasma.

Kerjasama dalam pengembangan kebun plasma, anggota koperasi diberi pinjaman atau kredit KKPA dari koperasi dengan syarat dan ketentuan sebagaimana diatur dalam perjanjian kredit yaitu masing-masing anggota koperasi menerima sebesar Rp. 21.365.700,- per kavling/paket (2ha). Kebun plasma akan diserahkan oleh Inti kepada anggota koperasi sebagai petani peserta terhitung sejak tanggal penyerahan sampai masa produktif tanaman. 
Pihak Inti akan melakukan rekavling pada tanah tersebut, membuat sarana prasarana yang diperlukan serta menyiapkan petak kebun sawit yang akan diserahkan kembali kepada anggota koperasi sesuai dengan hasil rekavling yang ditetapkan bersama antara Inti, Koperasi, dan Kelompok Tani. Proses rekavling selesai, petani diberi bibit kelapa sawit dan melakukan penanaman setelah bibit berumur 12 bulan, dalam kurun waktu 12 bulan tersebut petani juga diberikan bimbingan teknis dan penyuluhan. Petani melakukan pemeliharaan tanaman kelapa sawit seperti memberantas hama yang menggangu tanaman, memelihara kesuburan tanah dan menjaga keamanan kebun plasma terhadap bahaya-bahaya dari luar.

Anggota koperasi berkewajiban menjual produksi TBS dari hasil kebun kelapa sawit yang dikelolanya kepada inti melalui koperasi dengan mutu yang memenuhi standart yang ditentukan oleh inti. Inti berkewajiban membeli produksi TBS dari anggota koperasi dengan harga sesuai pedoman yang ditetapkan oleh pemerintah. Apabila selama masa kredit anggota koperasi tidak dapat memenuhi kewajibannya karena sebab-sebab diluar kemampuan kedua belah pihak seperti terjadi kerusakan sebagian atau seluruh kebun kelapa sawit (kejadian diluar kemampuan manusia dan tidak terduga) maka hal tersebut disampaikan secara tertulis kepada Inti melalui koperasi dengan terlebih dahulu disahkan oleh Kepala Desa dan Camat.

Peranan Koperasi dalam penyaluran KKPA yakni hanya sebagai koperasi primer, yakni koperasi yang beranggotakan orang seorang, bukan koperasi sekunder. Koperasi selaku penyalur kredit dalam rangka KKPA akan memperoleh imbalan dari hasil penjualan TBS kebun plasma yang besarnya ditentukan atas dasar kesepakatan dalam rapat anggota. Koperasi sebagai penyalur KKPA, maka koperasi tidak mempunyai tanggung jawab atas resiko pengembalian kredit.

Koperasi selaku penyalur mempunyai tugas untuk membuat pembukuan kredit angsuran yang telah dilakukan oleh anggota koperasi dan pembukuan kredit tersebut menjadi bukti tentang outstanding dari pinjaman anggota koperasi kepada koperasi. Koperasi wajib membuka tabungan replanting kepada Bank untuk menampung sebagian hasil penjualan TBS anggota koperasi yang dipergunakan untuk membiayai pembangunan kembali kebun plasma kelapa sawit milik anggota koperasi.

Akad Kredit dilakukan oleh Bank dengan masing-masing anggota penerima KKPA, yang diketahui oleh pengurus koperasi. Pelaksanaan Akad Kredit, para anggota diwakili oleh pengurus koperasi. Oleh karena itu, anggota penerima KKPA harus membuat Surat Kuasa kepada pengurus koperasi (Efairy, 2011).

Peran lain keporasi selain sebagai penyalur kemitraan, koperasi Bina Tani Sejahtera juga mempunyai peran sebagai pengawas dan menentukan harga kelapa sawit. Perusahan PT. Sawindo Kencana sebagai inti akan memberikan kuasa kepada koperasi untuk mengawas para anggota koperasi dalam menggunakan saprodi dan penjualan buah hasil dari anggota koperasi untuk diberikan ke pihak inti agar berjalan lancar. Para anggota koperasi diberi kemudahan oleh koperasi untuk menjual hasil dari panennya kepada pihak inti melalui koperasi, karena dengan adanya koperasi maka 
uang anggota koperasi akan terkontrol dan harga kelapa sawit akan stabil dengan harga yang telah ditentukan oleh pemerintah melalui rapat.

Perjanjian dan kesepakatan yang dapat dilihat dari realisasi kemitraan yang dilakukan antara PT. Sawindo dan Petani Telaga Biru sudah terealisasi dengan baik. Hal tersebut dilihat dari hubungan kerja sama yang dilakukan selama ini berjalan dengan baik, dan sesuai dengan prosedur yang berlaku. Dibalik hal tersebut kendala yang dimiliki oleh petani yaitu kurangnya tenaga kerja untuk memupuk, merawat, dan pada saat panen.

Kemitraan yang dijalankan meliputi saprodi yang berarti sarana produksi yang disediakan oleh perusahaan. Hal tersebut dilakukan mulai dari proses yang pertama yaitu produksi dimana segala pupuk, bibit telah disediakan oleh perusahaan yang akan diberikan kepada kelompok tani. Kedua yaitu pemasaran, dimana hasil panen dari petani akan dikelolah oleh perusahaan, sehingga petani tidak perlu repot dan sulit dalam menjual hasil panen. Berikut ini merupakan bagan yang menjelaskan tentang mekanisme kemitraan antara PT. Sawindo dan Petani Telaga Biru.

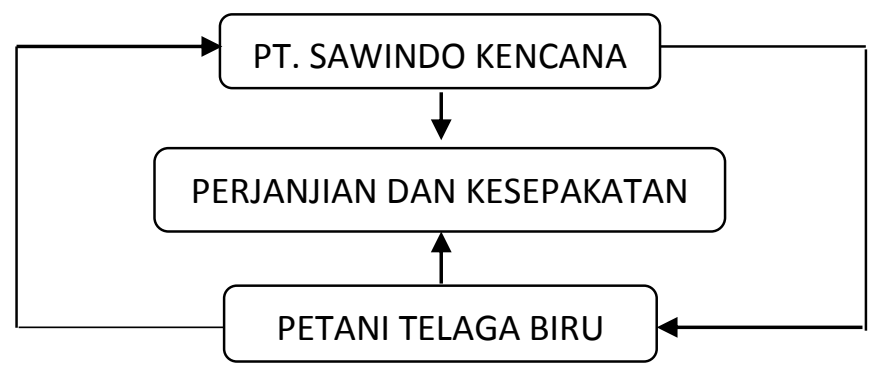

Gambar 1. Mekanisme Kemitraan antara PT. Sawindo Kencana dan Petani Telaga Biru.

\subsection{Hak dan Kewajiban}

Proses kemitraan tidak terlepas dari hak dan kewajiban antara PT. Sawindo Kencana dan Petani Telaga Biru. Hak merupakan sesuatu yang mutlak menjadi milik kita dan penggunaannya tergantung kepada kita sendiri, sedangkan kewajiban adalah sesuatu yg dilakukan dengan tanggung jawab (Thefasthorses, 2015).

Hak yang diperoleh oleh petani yaitu mendapatkan bibit, pupuk, alat panen, material pestisida dan pemasaran hasil panen, sedangkan hak-hak dari perusahaan adalah mendapatkan hasil panen yang berasal dari petani. Kewajiban yang harus dilakukan petani yaitu memberikan hasil panen kelapa sawit yang berkualitas / TBS (Tandan Buah Segar), sedangkan kewajiban dari perusahaan yaitu menyediakan apa yang dibutuhkan oleh petani seperti pupuk, alat panen, material pestisida, dan hak hasil panen. Berikut merupakan bagan yang menjelaskan kewajiban antara petani dan perusahaan. 


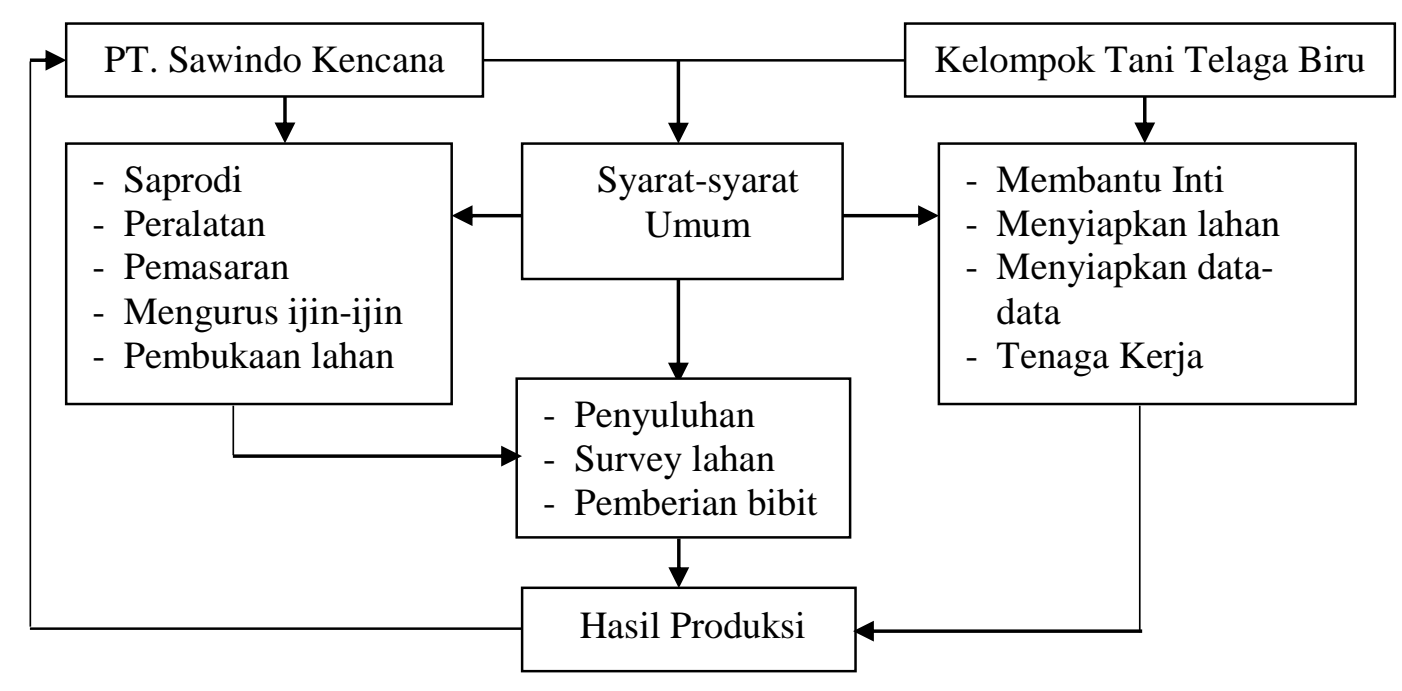

Gambar 2. Bagan Hak dan Kewajiban dalam Pola Kemitraan antara Kelompok Tani Telaga Biru dengan PT. Sawindo Kencana.

\subsection{Efektivitas Kerjasama}

Efektivitas adalah hasil membuat keputusan yang mengarahkan melakukan sesuatu dengan benar, yang membantu memenuhi misi suatu perusahaan atau pencapaian tujuan (Wijaya, 1993:32). Efektivitas dalam peran petani Telaga Biru terhadap perusahaan dalam kemitraan belum berjalan secara optimal. Hal tersebut dikarenakan kelompok petani Telaga Biru kebanyakan bukan petani murni, karena sebagian besar petani banyak bekerja sebagai nelayan, buruh, dan sebagian bekerja sebagai PNS (Pegawai Negeri Sipil). Berdasarkan hal tersebut, membuat efektifitas kerja sama menjadi belum optimal karena yang lebih efektif dalam kelompok tani adalah ketua kelompok saja dan petani yang murni.

Bila dilihat dari sisi peran PT. Sawindo Kencana, peran yang dilakukan sudah berjalan dengan baik. Hal tersebut dapat dibuktikan dalam hal perusahaan bertanggung jawab atas hasil yang telah dicapai hingga saat ini. Perusahaan berperan penting bagi petani dalam permasalahan pinjaman, karena pinjaman kredit dilakukan melalui bank ke koperasi dan perusahaan sebagai jaminan pinjaman, dan dari koperasi mengelola pinjaman tersebut untuk pembelian bibit sawit, dan peralatan yang dibutuhkan oleh petani, setelah itu barulah petani mendapatkan bibit dan peralatan yang dibutuhkan dari perusahaan yang di serahkan kepada koperasi.

Sistem pembayaran dilakukan secara kredit kepada Bank. Berikut penjelasan sistem pembayaran yang dilakukan oleh kelompok tani melalui bagan berikut ini. 


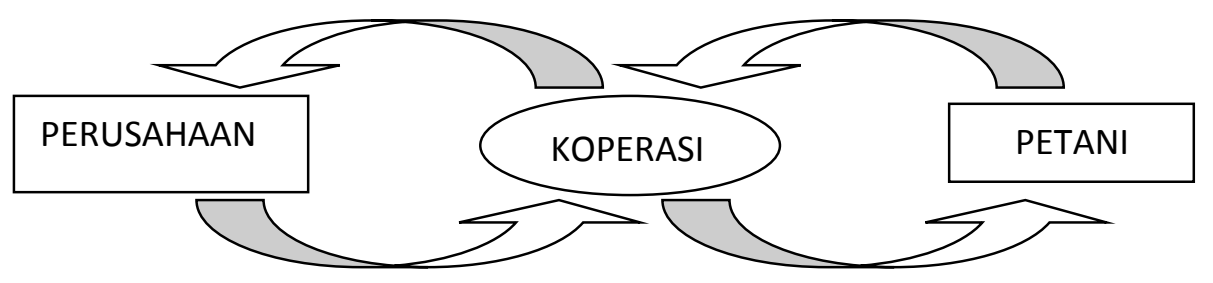

Gambar 3. Bagan Sistem dan Cara Pembayaran dalam Pola Kemitraan antara Kelompok Tani Telaga Biru dengan PT. Sawindo Kencana

Berdasarkan bagan tersebut, dijelaskan bahwa petani menyerahkan hasil panen kepada koperasi dan dilanjutkan ke perusahaan. Hasil penjualan panen yang diterima petani berasal dari perusahaan dan perusahaan menyerahkan kepada koperasi untuk mengelolah dan memberikan hasil tersebut kepada petani.

Penentuan harga beli kelapa sawit ditetapkan berdasarkan hasil rapat antara koperasi dan Dinas Perkebunan. Rapat dilakukan minimal satu (1) kali tiap bulan. Harga beli yang ditetapkan disesuaikan berdasarkan dengan harga jual minyak di pasar dunia maupun harga jual minyak pasar lokal.

\subsection{Kendala yang Dihadapi}

Pengertian kendala adalah menghalangi, rintangan, membatasi dan kekuatan yang memaksa pembatalan pelaksanaan (Setiawan, 2016), yang artinya adalah masalah yang muncul dalam budidaya kelapa sawit. Kendala yang terjadi dalam kelompok tani telaga biru adalah background petani yang berbeda-beda, karena kebanyakan petani di Desa Tanjung Niur sebagai nelayan bukan sebagai petani murni, sehingga petani kurang pengalaman dalam hal menanam yang baik. PT. Sawindo sebagai inti telah menurunkan teknisi untuk menyelesaikan masalah tersebut, seperti memberikan pengetahuan tentang membudidaya kelapa sawit kepada para petani di kelompok Telaga Biru.

Background petani yang berbeda ini memberikan dampak negatif bagi perekonomian petani itu sendiri, petani menjadi kurang disiplin untuk menyimpan uang hasil dari menjual panen karena jika sebagai nelayan petani bisa menghamburkan uang karena pasokan di laut sangat banyak, namun sebagai petani mereka harus bisa menabung untuk pada saat replanting. Koperasi Bina Tani sejahtera mempunyai peran penting untuk mengatasi masalah ini, dengan hasil panen yang didapat oleh petani harus dipotong untuk menabung, sehingga masalah untuk masa depan dapat teratasi.

Petani Telaga Biru kebanyakan bekerja sebagai nelayan dan pegawai negeri sipil (PNS) sehingga petani jarang untuk melihat kebun kelapa sawit mereka sendiri karena sibuk dengan pekerjaan utama. Ketua kelompok mempunyai peran penting dalam kemitraan ini, dimana ketua kelompok Tani Telaga Biru memegang kendali dalam memelihara kelapa sawit yang ditinggalkan petani bekerja sebagai nelayan dan pegawai negeri sipil, sehingga ketua kelompok harus menyewa pekerja baru untuk menangani saat pemupukan dan pemanenan. 


\section{Simpulan dan Saran}

\subsection{Simpulan}

Berdasarkan hasil dan pembahasan peneliti menarik kesimpulan sebagai berikut:

1. Mekanisme pelaksanaan kemitraan yaitu berdasarkan perjanjian tertulis antara Kelompok Tani Telaga Biru dengan PT. Sawindo Kencana yang sudah terealisasi dengan baik.

2. Hak yang diperoleh oleh petani yaitu mendapatkan bibit, pupuk, alat panen, material pestisida dan pemasaran hasil panen, sedangkan hak-hak dari perusahaan adalah mendapatkan hasil panen yang berasal dari petani. Kewajiban yang harus dilakukan petani yaitu memberikan hasil panen kelapa sawit yang berkualitas / TBS (Tandan Buah Segar), sedangkan kewajiban dari perusahaan yaitu menyediakan apa yang dibutuhkan oleh petani seperti pupuk, alat panen, material pestisida dan hak hasil panen.

3. Efektivitas Kerjasama yaitu kejelasan peran petani Telaga Biru terhadap perusahaan dalam kemitraan belum berjalan secara optimal namun sebaliknya peran yang dilakukan perusahaan sudah berjalan dengan baik. Hal tersebut dapat dibuktikan dalam hal perusahaan bertanggung jawab atas hasil yang telah dicapai hingga saat ini. Sistem pembayaran dilakukan secara kredit kepada Bank. Penentuan harga beli minyak sawit ditetapkan berdasarkan harga jual minyak di pasar dunia maupun harga jual minyak pasar lokal.

4. Kendala yang terjadi dalam kelompok tani telaga biru adalah background petani yang berbeda-beda sehingga memberikan dampak negatif bagi perekonomian dan pengalaman petani itu sendiri, petani menjadi kurang disiplin untuk menyimpan uang hasil dari menjual panen dan menanam yang baik. Petani Telaga Biru kebanyakan bekerja sebagai nelayan dan pegawai negeri sipil (PNS) sehingga petani jarang untuk melihat kebun kelapa sawit mereka.

\subsection{Saran}

Berdasarkan kesimpulan diatas peneliti memberikan saran sebagai berikut:

1. Petani harus lebih meningkatkan perannya dalam kelompok tani untuk menjalankan kemitraan.

2. Teknisi perusahaan harus lebih sering turun kelapangan untuk mengontrol pelaksanaan kemitraan dan mampu merangkul petani.

\section{Ucapan Terima Kasih}

Penulis mengucapkan banyak terimakasih kepada semua pihak yang telah membantu dalam pelaksanaan penelitian ini, terutama kepada pihak PT. Sawindo Kencana, Kelompok Tani Telaga Biru, dan Ketua Koperasi. 


\section{Daftar Pustaka}

Bagus, 1996. Pengertian mekanisme. http://www.definisimenurutparaahli.com /pengertian-mekanisme/. Diakses tanggal 29 oktober 2016.

Efairy, V. 2011. Pengertian KKPA. http://www.scribd.com/doc/57825817/ Pengertian-KKPA\#scribd/. Diakses tanggal 28 juni 2015.

Kurnianti. Novianti. 2013. Sistem Kemitraan dalam Usaha Agribisnis Pertanian. http://www.tanijogonegoro.com/2013/09/usaha-agribisnis-pertanian.html. Diakses tanggal 20 oktober 2015.

Setiawan, Ebta. 2016. Pengertian Kendala (KBBI). http://kbbi.web.id/kendala. Diakses tanggal 21 agustus 2016

Suharsaputra, U. 2012. Metode Penelitian Kuantitatif, Kualitatif dan Tindakan. Bandung : PT. Refika Aditama.

Sunarko, 2009. Budidaya dan Pengelolaan Kebun Kelapa Sawit dengan Sistem Kemitraan. Cetakan Pertama. Jakarta : Agromedia Pustaka.

Thefasthorses. 2015. Pengertian hak dan kewajiban menurut ahli pendidikan. https://aadrean.wordpress.com/2011/03/12/cara-membuat-daftar-pustaka-daribahan-yang-diambil-dari-internet/. Diakses tanggal 4 desember 2016.

Wijaya, Amin Tunggal. 1993. Manajemen Suatu Pengantar. Cetakan Pertama, Rineka Cipta Jaya, Jakarta. http://www.landasanteori.com/2015/10/pengertianefektivitas-kerja adalah.html. Diakses tanggal 12 desember 2016

Wiktionary, 2015. Informan. https://id.wiktionary.org/wiki/informan. Diakses tanggal 22 Desember 2015.

Yarsi, A. 2006. Analisis Pendapatan dan Penyerapan Tenaga Kerja pada Sistem Kemitraan Usaha Perkebunan Kelapa Sawit (Kasus Pola Kemitraan di PT. Perkebunan Nusantara VI dan PT. Bakrie Pasaman Plantation, Kabupaten Pasaman Barat Provinsi Sumatera Barat). Skripsi. Program Studi Ekonomi Pertanian dan Sumberdaya Fakultas Pertanian Institut Pertanian Bogor. Internet. http://repository.ipb.ac.id/handle/123456789/1098. Diunduh tanggal 18 Mei 2016. 